\title{
Exploring age, gender and area differences of teachers as regards mobile teaching
}

\author{
Gabriel Gorghiu, Elena Ancuța Santi \\ Valahia University Targoviste \\ 13 Aleea Sinaia, 130004 Targoviste, \\ Romania \\ ggorghiu@gmail.com, santi.anca@yahoo.ro
}

\author{
Costin Pribeanu \\ Academy of Romanian Scientists \\ 54 Splaiul Independentei, 050094 Bucharest, \\ Romania \\ costin.pribeanu@gmail.com
}

DOI: $10.37789 /$ rochi.2020.1.1.25

\begin{abstract}
Introducing mobile teaching and learning in schools represents a real challenge in nowadays education. Mobile devices are able to support a diversity of tasks such as communication, interaction, collaboration, information, and resource sharing. Although mobile devices are widely used for e-learning, but also very present in non-formal and informal learning, there are many barriers against the adoption of mobile technology by teachers, for teaching purposes. This paper analyzes the perceptions of Romanian teachers as regards the use of mobile technology in the teaching and learning process. The purpose of the paper is to explore the influence of gender differences, age, and area (urban vs. rural) on the perceptions of mobile teaching and learning. The results illustrate an important influence of such variables when considering the integration of mobile technology in education, as well as of a variable that has to be taken into consideration seriously: the teacher's attitude concerning the use of technology.
\end{abstract}

\section{Keywords}

Mobile devices, mobile learning, mobile teaching, group differences.

\section{ACM Classification}

D.2.2: Design tools and techniques. H5.2 User interfaces.

\section{INTRODUCTION}

Introducing mobile teaching and learning in schools is a challenge for more than a decade. Mobile devices are widely used by teachers and students for communication, interaction, socialization, collaboration, information, and resource sharing. Despite the familiarity of teachers with mobile devices, several barriers (external and internal) exist concerning the adoption of mobile technology in the teaching and learning process: technical skills needed to operate a computer, pedagogical models of technology use, teachers' personal beliefs, willingness to change, technology acceptance, lack of access, class disruption, time, training, institutional support [7, 14, 16, 18, 19].

The technology acceptance is driven by various factors, among which the most important are the perceived ease of use and the user's motivation [5]. In the context of the technology acceptance model (TAM), extrinsic motivation has been conceptualized as perceived usefulness and the intrinsic motivation has been conceptualized as perceived enjoyment [5].
Intrinsic motivation in TAM is related to user experience. Hornbaek and Hertzum [8] reviewed the relationship between technology acceptance and user experience and found that few studies are published that take into consideration the users' needs and the settings in which the technology is adopted.

Mobile devices are expected to increase students' motivation to learn and help them to better understand the lesson [13]. On another other hand, it is expected that teachers could better explain difficult concepts and better stimulate students. Understanding teachers' perception of the acceptance of mobile technology for teaching and learning also requires a closer look at demographic variables, such as gender and age [21].

Although introducing mobile devices in the teaching process creates many opportunities - as better understanding and increased motivation to learn $[13,21]-$, it seems to be a difficult task, requiring an additional effort for teachers: learning how to use the new technology, how to implement, and how to design thinking by teachers $[15,16,18,19]$.

The objective of this work is to analyze the perceptions of Romanian teachers as regards the use of mobile technology in the teaching and learning process. The analysis is done on a sample of 125 teachers along with three factors: (a) expectancy of students' motivation to learn, (b) expectancy of learning usefulness, and (c) teaching usefulness. The differences as well as the perceived barriers are further analyzed by three variables: gender, age, and area (urban vs. rural).

The rest of the paper is organized as follows. In section 2, related work is discussed with a focus on the acceptance of mobile technology in schools. The method and sample are presented in section 3 . Then, differences by gender, age, and area are analyzed and discussed in section 4 . The paper ends with a conclusion in section 5 .

\section{RELATED WORK}

The study of Mac Calum et al. [15] analyzed the drivers of teachers' acceptance of mobile teaching and learning. To do this, they extended TAM to include digital literacy, ICT anxiety, and ICT teaching self-efficacy. They found that these external variables have a significant influence on the factors that mediate the intention to use. Their study highlights the importance of digital skills needed to use mobile devices in the classroom as well as the need for support from the institution willing to promote mobile learning and teaching. 
Wang et al. [21] analyzed the factors that drive the acceptance of mobile learning by using the unified theory of acceptance and use of technology [20]. They found that performance expectancy (perceived usefulness), effort expectancy (perceived ease of use), perceived playfulness (perceived enjoyment) and learning self-management are the most important drivers of acceptance. An analysis of the age differences showed that effort expectancy and social influence were stronger predictors of the intention to use the technology for the elders. Also, a gender analysis showed that social influence was a stronger predictor for men than for women, while learning self-management was a stronger predictor for women. Several studies on the issue of gender differences in the use of technology show that male subjects have a positive attitude toward technology more than females $[4,12]$ and they also are more confident in their abilities to use technology in learning [22], and more interested in information technology [9], although other studies found no significant relationship for age and gender, and teachers' attitudes related to exploiting the computers [17]. However, in terms of using mobile technology in learning, the studies indicate different results: several researchers confirm the existence of gender and age differences, but also social and cultural influences that can act as barriers in the implementation of m-learning [2]; while Adedoja \& Morakinyo [1] show that there are no gender differences in the perceived usefulness of mobile devices in learning, in the easiness of using the means of mobile technology for learning, both categories showing a positive attitude towards m-learning.

Regarding the differences between urban and rural school teachers in the use of technology, Howley, Wood \& Hough [10] show that the attitude of teachers in rural schools is positive, but those teachers seem to have less adequate skills regarding the exploitation of technology in teaching and learning process.

\section{RESEARCH METHODOLOGY}

This research is part of a larger study that started with a qualitative study aiming to understand the barriers against and motivation towards the use of mobile devices in teaching and learning $[13,16]$. Based on the findings of preliminary research, an evaluation instrument has been developed, targeting several factors: motivation, learning usefulness, and teaching usefulness.

The questionnaire has been administrated during a pilot study to Romanian teachers in November-December 2019. The sample consists of 34 men and 91 women, distributed by age in groups, as follows: 15 teachers of 20-29 years, 27 teachers of 30-39 years, 29 teachers of 40-49 years, 43 teachers of 50-59 years, and 11 teachers over 60 years old. 93 teachers are working in the urban area and 32 in the rural area. First, teachers were asked to answer some general questions, then to rate several statements on a 5-points Likert scale, and last to answer two open-ended questions related to the barriers against mobile teaching and concerning the technical conditions met in their school.

The variables proposed and analyzed in this work, the mean values $(\mathrm{M})$ and standard deviation (SD) are presented in Table 1.
The differences by gender, age group, and area have been analyzed by mean comparison and the one-way ANOVA test for significance.

Table 1. Variables $(N=125)$

\begin{tabular}{|l|l|l|}
\hline Variable & $\mathrm{M}$ & $\mathrm{SD}$ \\
\hline Motivation to learn & & \\
\hline $\begin{array}{l}\text { By using mobile technology students may be less } \\
\text { bored by the traditional methods }\end{array}$ & 4.05 & 1.02 \\
\hline $\begin{array}{l}\text { By using mobile technology students may find } \\
\text { the lesson more } \text { attractive }\end{array}$ & 4.25 & 0.89 \\
\hline $\begin{array}{l}\text { By using mobile technology students are less } \\
\text { stressed, and learning is accepted } \text { as a game }\end{array}$ & 4.02 & 0.97 \\
\hline $\begin{array}{l}\text { By using mobile technology students may find } \\
\text { the lesson more } \text { interesting }\end{array}$ & 4.34 & 0.86 \\
\hline Learning usefulness & & \\
\hline $\begin{array}{l}\text { Mobile technology may help to learn } \text { outside the } \\
\text { class }\end{array}$ & 4.10 & 0.90 \\
\hline $\begin{array}{l}\text { Mobile technology may help the collaborative } \\
\text { learning }\end{array}$ & 4.08 & 0.83 \\
\hline Mobile learning stimulates creativity & 3.84 & 0.95 \\
\hline $\begin{array}{l}\text { Mobile technology may help to better } \\
\text { understand the lesson }\end{array}$ & 4.08 & 0.79 \\
\hline Teaching usefulness & 4.26 & 0.80 \\
\hline $\begin{array}{l}\text { With mobile technology, I could prepare more } \\
\text { interesting lessons }\end{array}$ & 4.06 & 0.79 \\
\hline $\begin{array}{l}\text { Mobile technology helps to give learning tasks to } \\
\text { students }\end{array}$ & 3.78 & 0.94 \\
\hline $\begin{array}{l}\text { With mobile technology, I could better } \text { explain } \\
\text { difficult concepts }\end{array}$ & 0.83 \\
\hline $\begin{array}{l}\text { With mobile technology, I could better } \text { stimulate } \\
\text { the students to learn }\end{array}$ & 3.97 \\
\hline
\end{tabular}

\section{ANALYSIS OF DIFFERENCES}

\section{Differences by gender}

The gender differences as regards the learning motivation, learning usefulness, and teaching usefulness are presented in Figure $1(\mathrm{M}=34, \mathrm{~F}=91)$.

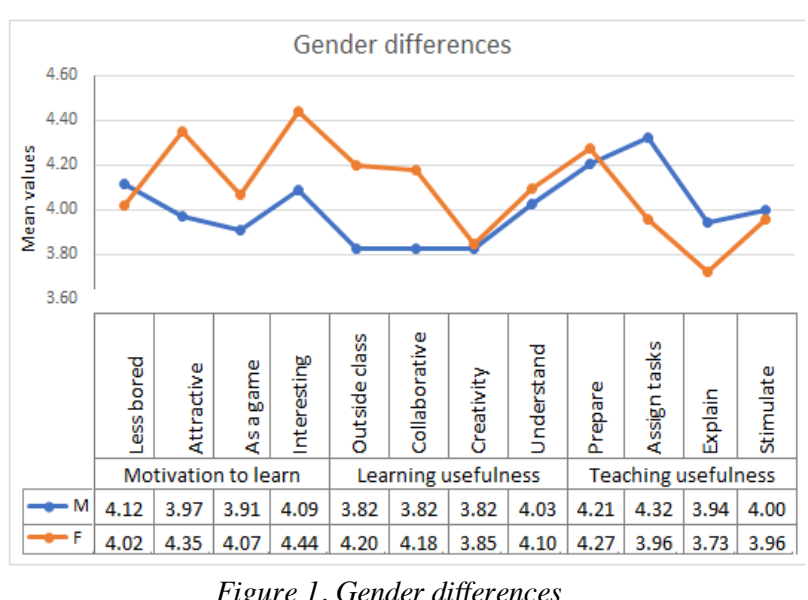

The perceptions of students' motivation expectancy and learning expectancy are higher in the case of female teachers. As regards the students' motivation to learn, the mean differences are higher and statistically significant (one-way 
ANOVA 1, 123, 124) for the expectancy of more attractive $(\mathrm{F}=4.72, \mathrm{p}=0.032)$ and more interesting lessons $(\mathrm{F}=4.42$, $\mathrm{p}=0.042$ ). As regards the expectancy of learning usefulness, female teachers also scored higher, the one-way ANOVA showing statistically significant differences for opportunities of learning outside the class $(\mathrm{F}=4.38, \mathrm{p}=0.038)$ and collaborative learning $(\mathrm{F}=4.60, \mathrm{p}=0.034)$.

With one exception, male teachers scored higher the items related to teaching usefulness. The one-way ANOVA showed that only one difference is statistically significant, related to assigning learning tasks to students $(\mathrm{F}=5.61$, $\mathrm{p}=0.019$ ).

As regards the barriers against the adoption of mobile technology for teaching, most frequently mentioned were the lack of equipment and/or Internet connection in school ( $81 \%$ of teachers) and the lack of skills (32\% of male teachers and $42 \%$ of female teachers). Other mentioned barriers were: the potential of misuse of mobile devices and the lack of funds.

\section{Differences by the age groups}

The differences by the age groups are illustrated in Figure $2(\mathrm{~N}=15 / 27 / 29 / 43 / 11)$.

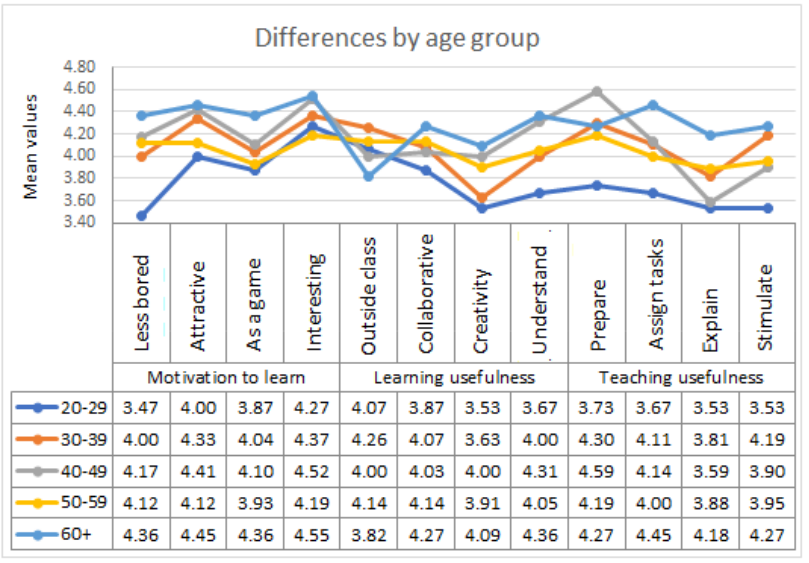

Figure 2. Age group differences

Overall, younger teachers (20-29 years) seem to have the lowest confidence in mobile teaching and learning. On the contrary, teachers over 60 years old have the highest perceptions with one exception.

A one-way ANOVA $(4,120,124)$ shows a statistically significant difference for the opportunity to prepare more interesting lessons $(\mathrm{F}=3.12, \mathrm{p}=0.02)$ and a marginal significance for better understanding expectancy $(\mathrm{F}=2.17$, $\mathrm{p}=0.076$ ).

The lack of skills needed to adopt mobile teaching has been mentioned mainly by older teachers, respectively $64 \%$ of teachers over 60 years old, $48 \%$ of teachers having $40-49$ years old, and $37 \%$ of teachers having $50-59$ years old.

\section{Differences by area}

The differences by the area where the school is located are presented in Figure 3 (urban=93, $\mathrm{N}=26$ ).

Overall, teachers working in rural areas have a higher perception related to the learning motivation and usefulness brought by the presence of mobile technology.
A one-way ANOVA $(1,123$ 124) shows that the differences are statistically significant for the following variables: the expectancy of attractive lessons $(\mathrm{F}=4.52, \mathrm{p}=0.035)$, more interesting lessons $(\mathrm{F}=5.86, \mathrm{p}=0.017)$, and collaborative learning $(\mathrm{F}=6.98, \mathrm{p}=0.009)$. The differences are marginally significant for better understanding expectancy $(\mathrm{F}=3.82$, $\mathrm{p}=0.053$ ) and the opportunity to better explain difficult concepts $(\mathrm{F}=3.03, \mathrm{p}=0.084)$.

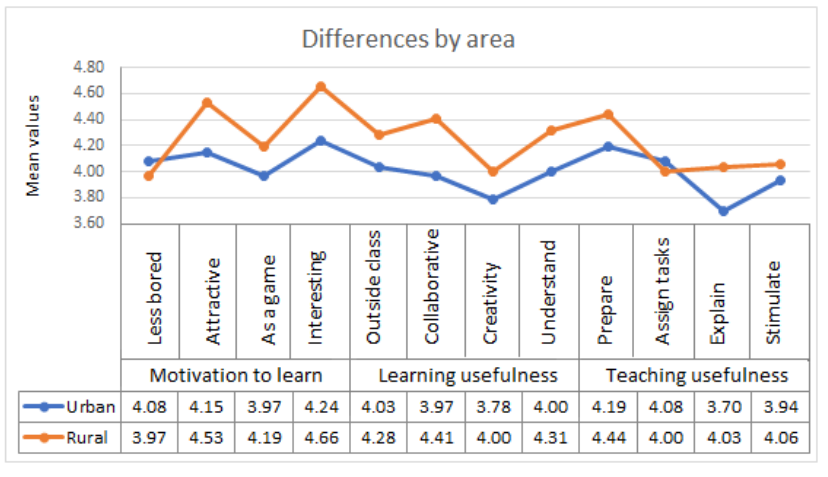

Figure 3. Area differences

As regards the barriers, the lack of equipment and/or Internet connection was mentioned by $75 \%$ of teachers working in the urban area and $85 \%$ of teachers working in a rural area, while the lack of skills was mentioned by $39 \%$ of teachers working in the urban area and $38 \%$ of teachers working in rural areas.

\section{DISCUSSION}

The results of the study show that there are gender differences concerning the teachers' perception of the role of mobile technology in teaching and learning. Female teachers consider more than males that mobile technology represents a motivational variable for students (lessons become more attractive, more interesting) and useful in learning (create opportunities of learning outside the class and collaborative learning). Male teachers appreciate that mobile technology is perfect for assigning learning tasks to students, being also useful for explaining theoretical notions.

The results are similar to the findings of researches, who identified gender as an important variable in the way that teachers perceive and use technology in education. We appreciate those differences as related to intrinsic factors mainly with the teaching style and personal vision on education, but also cultural and social factors (according to [2]). Also, the results illustrate the age as a factor that influences mobile teaching. Interestingly, young teachers do not benefit in a great manner of such opportunities - a possible explanation could be that beginners are usually focused on getting teaching positions in rural schools, but the schools' facilities and also the students' financial possibilities are limited on using modern technology in the educational process (lack of equipment and/or Internet connection, in many cases). Anyway, it is important to notice that teachers of 60+ recorded good scores, but the 50-59 age group and the 40-49 years old teachers show more availability for using mobile technology in teaching and learning, being groups with rich experience, possibilities and facilities in schools, also with a great interest for the career (according to with the psychosocial development stages of Erikson's theory). 
Similar to Howley, Wood \& Hough [10], the results indicate that teachers from rural schools have a higher perception concerning the increase of learning motivation and usefulness of mobile teaching, although in many cases, they face much more difficulties than in schools from the urban areas.

By sure, there are limitations of this exploratory study. First, the sample of the research is not very extensive (125 subjects), so that the results cannot be generalized at the national level. Secondly, the distribution by gender and area is not very balanced: 34 men and 91 women, with 93 teachers working in the urban area and 32 in the rural area. Another limitation is coming from the research itself: it is based, at this level, only on the teacher's perceptions and answers the student's perspective or other evaluation issues are missing, so that it may induce a subjective factor.

\section{CONCLUSION AND FUTURE WORK}

This study contributes to a better understanding of the factors that drive the adoption of mobile technology for teaching and learning. The results show that a series of variables can influence the process of integrating modern technology into education (age, gender, local area), but also the attitude of teachers remains important: teachers who value such resources as necessary and useful improve their teaching knowledge and can build meaningful learning experiences for students. In the actual society, technology has become indispensable and teachers must have not just specific equipment at their disposal, but also necessary digital skills and abilities, as well as a desire and ambition for changing the educational process, by considering the student in its central point.

\section{REFERENCES}

1. Adedoja, G., Morakinyo, D. A. (2016). Gender Influence on Undergraduates Students' Acceptance of Mobile Learning Instruction using Technology Acceptance Model (TAM). Asian Journal of Education and e-Learning, 4(2), 65-70.

2. Al-Hunaiyyan, A., Alhajri, R., Al-Sharhan, S. (2017). Instructors Age and Gender Differences in the Acceptance of Mobile Learning. International Journal of Interactive Mobile Technologies, 11(4), 4-15. DOI: 10.3991/ijim.v11i4.6185

3. Chiu, T., Churchill, D. (2016) Adoption of mobile devices in teaching: changes in teacher beliefs, attitudes, and anxiety, Interactive Learning Environments, 24(2), 317-327, DOI: 10.1080/10494820.2015.1113709

4. Comber, C., Colley, A. (1997). The effects of age, gender and computer experience upon computer attitudes. Educational Research, 39(2), 123-133.

5. Davis, F. D., Bagozzi, R. P., Warshaw, P. R. (1992). Extrinsic and intrinsic motivation to use computers in the workplace. Journal of Applied Social Psychology, 22(14), 1111-1132.

6. Erikson, E.H. (1982) The life cycle completed. New York: Norton.

7. Ertmer, P. A. (1999). Addressing first-and secondorder barriers to change: Strategies for technology integration. Educational technology research and development, 47(4), 47-61.
8. Hornbæk, K., Hertzum, M. (2017). Technology Acceptance and User Experience: A Review of the Experiential Component in HCI. ACMTrans. Comput.Hum. Interact. 24(5), Article 33 (October 2017), 30 pages, DOI: $10.1145 / 3127358$.

9. Houtz, L. E., Gupta, U. G. (2001). Nebraska high school students' computer skills and attitudes. Journal of Research on Computing in Education 33(3) 316-328.

10. Howley, A., Wood, L., \& Hough, B. (2011). Rural elementary school teachers' technology integration. Journal of Research in Rural Education, 26(9), 1-13.

11. Huang, J. H., Lin, Y. R., Chuang, S. T. (2007). Elucidating user behavior of mobile learning. The electronic library, 25(5), 585-598.

12. Kadijevich, D. (2000). Gender differences in computer attitude among ninth-grade students. Journal of Educational Computing Research, 22(2), 145-154.

13. Lamanauskas, V., Slekiene, V., Gorghiu, G., Pribeanu, C. (2019). Better learning and increased motivation to learn with mobile technology (devices): A preliminary study. Natural Science Education 16(2), 80-88.

14. Leem, J., Sung, E. (2019). Teachers' beliefs and technology acceptance concerning smart mobile devices for SMART education in South Korea. British Journal of Educational Technology, 50(2), 601-613. https://doi.org/10.1111/bjet.12612

15. Mac Callum, K., Jeffrey, L., Kinshuk. (2014). Factors impacting teachers' adoption of mobile learning. Journal of Information Technology Education: Research, 13, 141-162.

16. Pribeanu, C., Gorghiu, G., Lamanauskas, V., Slekiene, V. (2020) Use of mobile technology in the teaching/learning process: opportunities and barriers. Proceedings of ELSE 2020 Conference, Vol I, 376383, DOI: 0.12753/2066-026X-20-049.

17. Teo, T. (2008). Pre-service teachers' attitudes towards computer use: A Singapore survey Australasian Journal of Educational Technology, 24(4), 413-424, DOI: 10.14742/ajet.1201.

18. Tsai, C. C., Chai, C. S. (2012). The "third"-order barrier for technology-integration instruction: Implications for teacher education. Australasian Journal of Educational Technology, 28(6), 1057-1060.

19. Thomas, K., O'Bannon, B., Bolton, N. (2013). Cell Phones in the Classroom: Teachers' Perspectives of Inclusion, Benefits, and Barriers, Computers in the Schools, 30(4), 295-308.

20. Venkatesh, V., Morris, M. G., Davis, G. B. Davis, F. D. (2003). User acceptance of information technology: toward a unified view. MIS Quarterly, 27(3), 425-478.

21. Wang, Y. S., Wu, M. C., Wang, H. Y. (2009). Investigating the determinants and age and gender differences in the acceptance of mobile learning. British Journal of Educational Technology, 40(1), 92-118.

22. Yau, H. K., Cheng, A. L. F. (2012). Gender Difference of Confidence in Using Tehnology for Learning. Journal of Technology Studies, 38(2), 74-79. 